\title{
Injuries in humans caused by mantis shrimp or siriboia (Crustacea: Stomatopoda)
}

\author{
Antonio Lucas Sforcin Amaral ${ }^{[1]}$, Antonio Leão Castilho ${ }^{[1]}$ and Vidal Haddad Junior ${ }^{[2]}$ \\ [1]. Universidade Estadual Paulista, Instituto de Biociências de Botucatu, Departamento de Zoologia, Botucatu, SP, Brasil. \\ [2]. Universidade Estadual Paulista, Faculdade de Medicina de Botucatu, Departamento de Dermatologia e Radioterapia, Botucatu, SP, Brasil.
}

\begin{abstract}
Introduction: Mantis shrimps or siriboias are crustaceans belonging to the order Stomatopoda. They are known for their strong claws, which they use for defense and capturing their prey. They are classified into two groups: the spearers, which pierce the prey with sharp projections, and the smashers, which strike their prey with high-powered punches. These animals are highly feared by fishermen, and there are frequent anecdotal reports of human injuries caused by these crustaceans. Methods: A questionnaire about injuries in humans caused by these stomatopods was administered to 23 fishermen of Colony Z10 in Ubatuba, São Paulo state, Brazil, and a survey of the literature on injuries in humans caused by these animals was carried out. Results: The fishermen consider the mantis shrimp dangerous and avoid direct contact with them on account of the associated risk. We describe five reports of human injuries caused by these animals: four by the claws and one by the tail spikes. Conclusions: We describe the first aid treatment, prevention, and recommendations for such cases and propose the distribution of educational leaflets among the fishermen colonies.
\end{abstract}

Keywords: Arthropoda. Crustacea. Injuries. First aid. Occupational diseases.

\section{INTRODUCTION}

The mantis shrimp (Figure 1) is a marine crustacean belonging to the order Stomatopoda Latreille, 1817, and popularly known as siriboia, tamarutaca, tamburutaca, boxing shrimp, or squilla. "Siriboia" is an indigenous word formed by joining the words " $s i$ ' $r i$ " (crab) and "mboi" (snake/serpent)1. They are known as "mantis shrimp" because they possess raptorial claws with which they attack their prey like a mantis (Insecta: Mantodea), which strikes using its forelegs. Mantis shrimps have a global distribution and occur in tropical and subtropical waters ${ }^{2-4}$. In Brazil, there are 43 species belonging to 10 families, with a wide geographic distribution along the coast, from Amapá state (latitude $03^{\circ}$ north) to Rio Grande do Sul state (latitude $30^{\circ}$ south) ${ }^{5-8}$.

These animals stand out for their ability to strike prey with the second thoracic legs that are modified into raptorial claws (Figure 1A and B $)^{9}$. There are two morphological types of

\footnotetext{
Corresponding author: Antonio Lucas Sforcin Amaral.

e-mail: antoniosfamaral@gmail.com

(iD) https://orcid.org/0000-0001-9903-1509

Received 10 December 2020

Accepted 31 March 2021
}

claws that have different functions and based on which mantis shrimps are separated into two groups. The first group, known as spearers, possess claws that have three to eleven spear-like pointed projections, which are launched open when approaching the prey and close when reaching it. Thus, they capture and spear the prey with the claw-projections that pierce the body of the prey, preventing its escape (Figure 1B, C, and E) ) $^{5,9-11}$. These animals can strike at speeds reaching $6 \mathrm{~m} / \mathrm{s}$ (approximately $21 \mathrm{~km} / \mathrm{h})^{12}$. They usually occupy burrows in sandy sediments ${ }^{13,14}$.

The second group, known as smashers (Figure 1F), is represented by species whose claws have a big, calcified protrusion at the base, with which they strike the target at speeds reaching 30.6 $\mathrm{m} / \mathrm{s}$ (about $108 \mathrm{~km} / \mathrm{h}$ ) with an impact of 1500 Newtons (about 152 $\mathrm{kg}$ ), which is the acceleration equivalent to that of a projectile shot from a $9 \mathrm{~mm}$-caliber pistol ${ }^{9,15-17}$. These animals inhabit burrows in rocks and corals ${ }^{12-14,18}$.

In addition to the claws, these stomatopods have two uropods, which are structures in the tail that constitute the "caudal fan" (Figure 1C). The uropods have a pair of pointed spikes each (Figure 1D) that can also be used as a weapon ${ }^{14}$.

The fishermen fear the "siriboia," both in their fishnets and while walking in shallow waters during the low tide. In some parts 


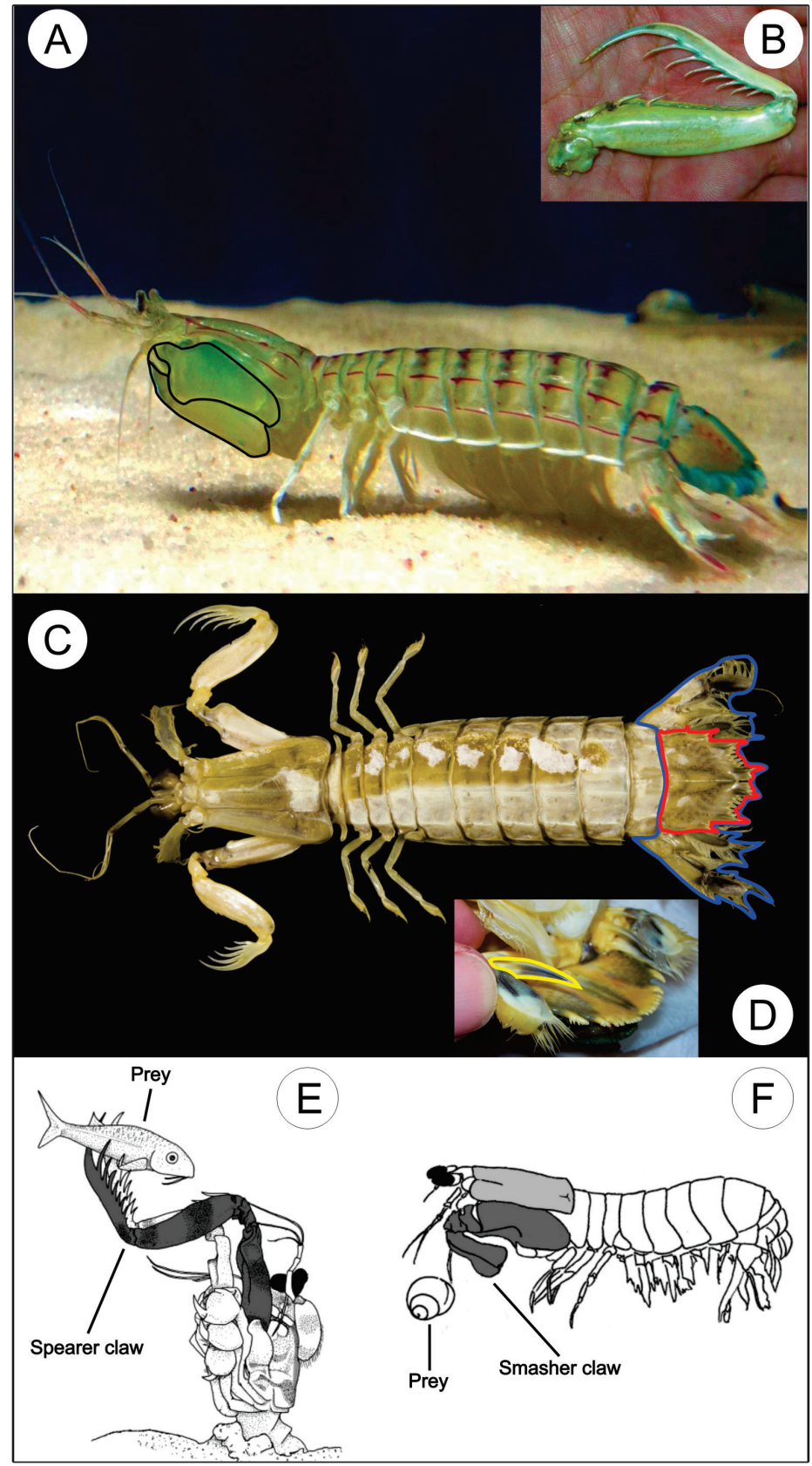

FIGURE 1: (A) Mantis shrimp in side view showing the raptorial claw (black outline); (B) The raptorial claw; (C) Gibbesia neglecta in dorsal view, showing the telson (red outline) and caudal fan (blue outline); (D) Sharp projection (yellow outline) on the uropod, below the telson; (E) A spearer stomatopod holding its prey within the sharp projections of its claw (adapted from deVries et al., 2012); (F) A smasher stomatopod striking its prey (adapted from Cox et al., 2014). Illustration composition ( $E$ and $F$ adapted from Anderson et al., 2014).

of the Caribbean, the stomatopods are called "thumb splitter shrimp", which highlights their ability to cause injuries ${ }^{19,20}$. These animals are difficult to observe. Further, the information on the injuries they cause to fishermen is limited ${ }^{21}$. Therefore, we aimed to identify and describe:

1. Injuries previously recorded in the literature or from unpublished data gathered by specialists on injuries caused by marine animals.

2. The occurrence of injuries in the fishermen colony, Z10 located in Ubatuba, São Paulo, Brazil, through an interview process.

\section{METHODS}

\section{Bibliographic research}

A literature search was performed to look for reports of injuries in humans caused by mantis shrimps, recorded by health and/or zoological professionals, with experience in fishermen colonies. The reports were studied to identify the circumstances of the injury and the aspect of the wound to understand how the injuries occur and which sequelae they can cause.

It included articles and notes published in peer-reviewed periodicals that provided information about the stomatopods and their relation with fishermen as well as books related to the subject written by researchers with experience in injuries caused by marine animals.

\section{Data collection}

The municipality of Ubatuba $\left(23^{\circ} 26^{\prime} 2^{\prime \prime}\right.$ South, $45^{\circ} 5^{\prime} 9^{\prime \prime}$ West $)$ is located in the southeast region of Brazil, on the north coast of São Paulo state, in an area with open sea areas and estuaries ${ }^{22}$. The fishermen colony, Z10 in Ubatuba was chosen for the administration of a stratified questionnaire because it was easier to approach the fishermen here. The workers present in the colony at the time of interview were requested to answer the questions after providing consent and on confirming that they worked as fishermen in the colony. Those who did not work as fishermen in the colony were excluded. The fishermen who met the same criteria as indicated by the interviewees were also interviewed.

The questionnaire that was administered by the interviewer contained queries regarding the injuries caused by the stomatopods, together with images of the animals for proper identification. The questions asked were as follows:

- Have you heard of siriboias/tamburutacas?

- Are siriboias/tamburutacas dangerous?

- Did you suffer from injuries due to siriboias/tamburutacas?

- If yes, how and where did it happen?

- Do you have any sequelae due to the injury?

- Do you know anyone who has had an injury caused by siriboias/tamburutacas?

The answers obtained were recorded through handwritten notes and counted at the end of the interviews. Information that was not directly related to the applied question was recorded when it provided relevant facts about the interaction between the stomatopods and humans. The descriptions of four cases of injury caused by the stomatopods observed by the authors on other occasions were added to the results; they complement the validity of the fishermen's answers obtained from the questionnaire.

\section{Ethics statement}

The authors were granted approval to conduct studies with fishermen from the Fish Market of Ubatuba and village of Picinguaba by the Ethics Committee in Human Experimentation of Faculdade de Medicina de Botucatu, São Paulo State University, under registration CAAI 59887316.5.0000.5411, report number 1.759.505 and by the Healthcare Department of Ubatuba, São Paulo. 


\section{RESULTS}

All the 23 fishermen who were interviewed reported knowing the stomatopods. Further, all the interviewees stated that they considered these animals dangerous, although none of them had been injured or experienced sequelae. However, five fishermen $(21.7 \%)$ reported knowing people who had been injured by these crustaceans. One of these cases included that of a fisherman, about 50 years old, who caught a stomatopod from a sandy substrate (Figure 1E) using a fishing rod. When trying to remove it from the hook, he held the animal by the claws to avoid being injured. However, he was struck on his hand with its tail, that caused perforations through the tail spikes, resulting in bleeding and pain. One of the interviewees reported that it is possible to manipulate the smaller specimens, when necessary, by taking hold of their abdomen and folding it, so that the claws and uropod are in contact, thereby rendering them unable to injure the hands.

Four records of injuries caused by the stomatopods have been described and observed in other situations ${ }^{20,23}$; they justify the fact that it is important for fishermen to be wary of these animals.

Case 1: A 24-year-old fisherman was injured while manipulating a fishing net in the "curral" (wooden structures that trap the fish, making them easy to catch) in Salinópolis, Pará state, Brazil. The stomatopod, which he did not notice in the net, struck his hand with its claws, hitting the fifth left finger and the second right finger, causing tissue laceration and severe pain, which lasted for about an hour. He reported that he washed the area intensively with soap and water, and complete healing occurred in about one week.

Case 2: A 54-year-old fisherman in Ubatuba, São Paulo state, Brazil, was wounded three times on his hands by the stomatopods while fishing for shrimp. He informed that the animal was easily found in the fishing nets and had scars on his fingers that had been caused by the previous injuries (Figure 2A). He further reported that he did not undergo any treatment for the wounds when they occurred, and they persisted for weeks without healing ${ }^{23}$.

Case 3: A 22-year-old fisherman in Ubatuba, São Paulo state, Brazil, was wounded by a stomatopod when disembarking and removing the net with fish. He stepped on something and felt intense pain in the medial malleolus of his right foot. He reported seeing the stomatopod because the water was clear in the spot, although he was unable to capture it. The area bled heavily, and the wound persisted for months (Figure 2B). At the time of recording the interview, there was an extensive scar in the $\operatorname{area}^{20}$.

Case 4: A 25-year-old biology student in Ubatuba, São Paulo state, Brazil, was injured on his left hand by a stomatopod while handling a specimen during a field study (Figure 2C). The claws caused a deep laceration with heavy bleeding, resulting in an ulcer that healed after approximately three weeks. The animal was not collected for subsequent identification.

\section{DISCUSSION}

The interviews we conducted indicate that fishermen know how these crustaceans cause injuries. They stated that the claw is dangerous, and caution is necessary to avoid getting hurt. The results

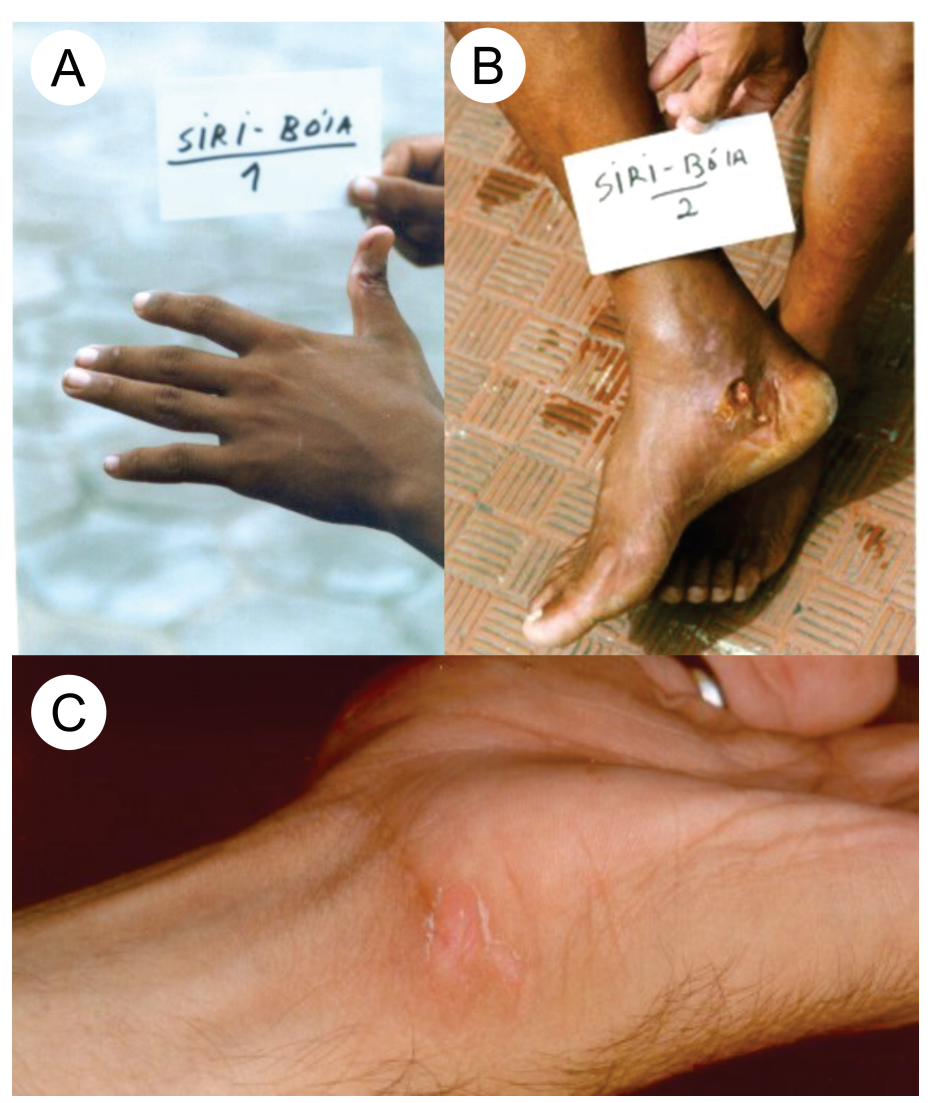

FIGURE 2: (A) Scars from injuries caused by a stomatopod, as described in case 2; (B) Injury on the right foot of a fisherman caused by a stomatopod, as described in case 3; (C) Injury on the left hand caused by a stomatopod, as described in case 4; tissue loss is seen in the wound due to the injury. Photo B was taken by Dr. João L. C. Cardoso.

showed that the stomatopods can cause injuries to humans when manipulated in fishing nets or rods, when stepped on in the sandy bottom, or in an attempt to capture them manually. The structure of the claws of both the spearers and smashers are highly specialized for capturing prey and have potential to cause injury in humans.

These animals have great strength and speed, as indicated by the injury depicted in Figure 2C; there is local tissue loss; however, it is not possible to precisely determine whether the wound was caused by a spearer or smasher. In Figure 2B, the wound appears to be deeper and has a rounded shape, which indicates a great focal impact; therefore, it might have been caused by a specimen with smasher claws.

The information that we obtained was organized in a chart to help health professionals and researchers study the data about the injuries (Figure 3).

There are no guidelines on prevention of injuries caused by the stomatopods, possibly because such incidents rarely occur. Based on the information obtained in this research, we recommend the following procedure for treating injuries caused by the stomatopods:

\section{Intensive washing and surgical exploration}

\section{Prevention of tetanus}

Antibiotic therapy: Cephalexin $2 \mathrm{mg} /$ day for 10 days or amoxicillin and potassium clavulanate $1.5 \mathrm{mg} /$ day for 10 days $^{21}$. 


\begin{tabular}{|c|c|c|c|c|c|c|c|c|}
\hline OCCUPATION & AGE & LOCATION & $\begin{array}{l}\text { ACTIVITY AT THE } \\
\text { TIME OF INJURY }\end{array}$ & $\begin{array}{l}\text { CAUSING } \\
\text { STRUCTURE }\end{array}$ & $\begin{array}{l}\text { INJURY } \\
\text { LOCATION }\end{array}$ & $\begin{array}{l}\text { CLINICAL } \\
\text { CONDITION }\end{array}$ & DEVELOPMENT & $\begin{array}{l}\text { TREATMENT } \\
\text { APPLIED }\end{array}$ \\
\hline Fisherman & 24 & $\begin{array}{l}\text { Salinópolis } \\
\text { PA }\end{array}$ & Handling fishing net & Claw & $\begin{array}{l}\text { Fifth left finger } \\
\text { and second right } \\
\text { finger }\end{array}$ & $\begin{array}{l}\text { Tissue laceration, } \\
\text { bleeding, pain }\end{array}$ & $\begin{array}{c}\text { Pain subsided after an } \\
\text { hour, healing after a } \\
\text { week }\end{array}$ & $\begin{array}{l}\text { Washing with } \\
\text { soap and water }\end{array}$ \\
\hline Fisherman & 22 & $\begin{array}{c}\text { Salinópolis } \\
\text { PA }\end{array}$ & $\begin{array}{l}\text { Removing the } \\
\text { fishing net from the } \\
\text { deck }\end{array}$ & Claw & $\begin{array}{l}\text { Medial malleolus } \\
\text { of the right foot }\end{array}$ & $\begin{array}{l}\text { Tissue laceration, } \\
\text { bleeding, pain }\end{array}$ & $\begin{array}{l}\text { Lesion persisted for } \\
\text { months until healing }\end{array}$ & No information \\
\hline Fisherman & 54 & $\begin{array}{l}\text { Ubatuba } \\
\text { SP }\end{array}$ & Fishing shrimps & Claw & $\begin{array}{l}\text { Three times in the } \\
\text { hands }\end{array}$ & $\begin{array}{l}\text { Tissue laceration } \\
\text { resulting in scars }\end{array}$ & $\begin{array}{l}\text { Lesions persisted for } \\
\text { weeks until healing }\end{array}$ & No information \\
\hline $\begin{array}{l}\text { Biology } \\
\text { student }\end{array}$ & 25 & $\begin{array}{l}\text { Ubatuba } \\
\text { SP }\end{array}$ & Field study & Claw & Left hand & $\begin{array}{l}\text { Tissue laceration, } \\
\text { bleeding, pain }\end{array}$ & $\begin{array}{l}\text { Ulcer that healed in } \\
\text { three weeks }\end{array}$ & No information \\
\hline Fisherman & 50 & $\begin{array}{l}\text { Ubatuba } \\
\text { SP }\end{array}$ & $\begin{array}{l}\text { Removing the } \\
\text { Stomatopoda from } \\
\text { the hook }\end{array}$ & Uropod & Hand & $\begin{array}{l}\text { Perforations, } \\
\text { bleeding, pain }\end{array}$ & No information & No information \\
\hline
\end{tabular}

FIGURE 3: Chart with description of the cases of injuries caused by stomatopods and their outcomes.

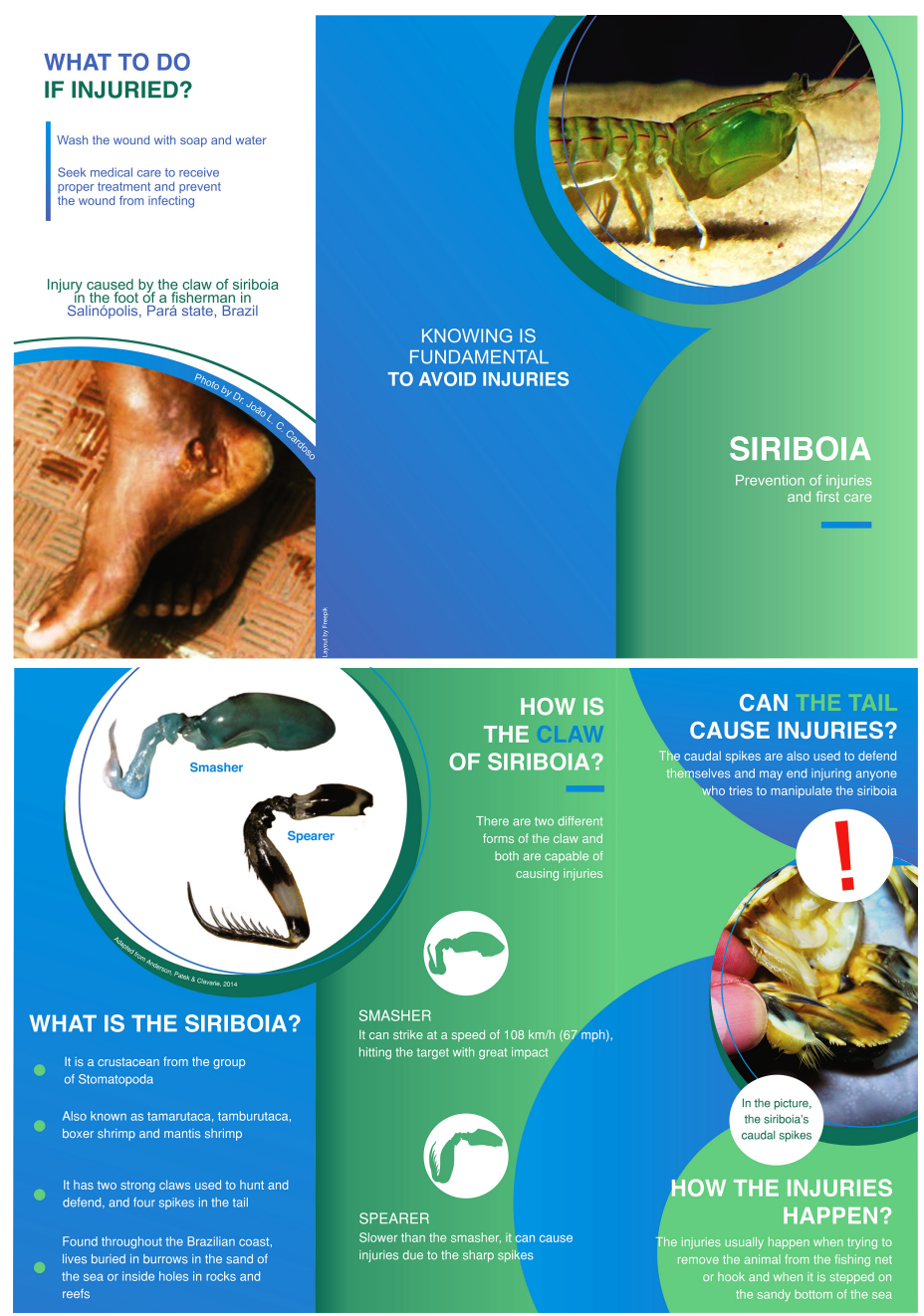

FIGURE 4: Educational leaflet about injuries caused by stomatopods.

For educational and injury-prevention purposes, we used the data obtained to prepare an informative leaflet (Figure 4) to be distributed to the fishing colony where the study was conducted. It is a compilation of information on the stomatopods, the risks associated with improper handling, and treatment protocols in case of injuries. This initiative aims to reduce the lack of information and injuries caused by the stomatopods.

\section{ACKNOWLEDGMENTS}

The authors are thankful to Dr. Débora Lucatelli for her contribution with Stomatopoda species identification, and Conselho Nacional de Desenvolvimento Científico e Tecnológico for the financial support.

\section{FINANCIAL SUPPORT}

Conselho Nacional de Desenvolvimento Científico e Tecnológico CNPq process number 132848/2018-0.

\section{AUTHORS' CONTRIBUTION}

ALSA: Conception of the study, carried out the interviews, discussed the results, wrote the manuscript and drafting the article; ALC: Supervised the project and manuscript writing, approval of the version to be submitted; VHJ: Conception of the study and structure of the manuscript, carried out the interviews, supervised the project and findings of this study, discussed the final manuscript, final approval of the version to be submitted.

\section{CONFLICT OF INTEREST}

The authors declare no conflict of interests during this work's development and in its conclusion.

\section{ORCID}

Antonio Lucas Sforcin Amaral: 0000-0001-9903-1509

Antonio Leão Castilho: 0000-0003-0001-9054

Vidal Haddad Junior: 0000-0001-7214-0422

\section{REFERENCES}

1. Tibiriçá LC. Vocabulário Tupi Comparado: contribuição ao estudo da etimologia e das origens da família linguística tupi-guarani. 3rd ed. Brasil: Traço Editora; 1997. 139 p.

2. Abelló P, Martín P. Fishery dynamics of the mantis shrimp Squilla mantis (Crustacea: Stomatopoda) population off the Ebro delta (northwestern Mediterranean). Fish Res. 1993;16(2):131-45. Available from: http://dx.doi.org/10.1016/0165-7836(93)90048-C 
3. Campos E. Distribution and host for four symbiotic crustaceans of the Mexican Pacific (Stomatopoda and Decapoda). Bull South Calif Acad Sci. 1995;94:176-8.

4. Kawamura Y, Hamano T, Kagawa T. Distribution of larvae and juveniles of the Japanese mantis shrimp Oratosquilla oratoria (De Haan, 1844) (Stomatopoda) in the Sea of Hiuchi-Nada, Japan. Crustac Res. 1997;26:75-82.

5. Manning RB. Stomatopod Crustacea of the Western Atlantic (Studies in Tropical Oceanography, No 8). Coral Gables, Florida: University of Miami Press; 1969. 360 p.

6. Coelho PA, Koening ML. A distribuição dos crustáceos pertencentes às ordens Stomatopoda, Taiadacea e Isopoda no Norte e Nordeste do Brasil. Trop Oceanogr. 1972;13:245-59.

7. Amaral ACZ, Lana PC, Fernandes FC, Coimbra JC. Biodiversidade bêntica da região Sul-Sudeste da costa brasileira. Revizee: Score Sul Bentos. São Paulo: Edusp; 2003. 156 p.

8. Lucatelli D, Bezerra LEA, dos Santos PJP, Coelho PA. Checklist of Stomatopoda (Malacostraca: Hoplocarida) deposited in the MOUFPE collection, with a new record from Brazil. Nauplius. 2012;20(2):257-93.

9. Patek SN. The Power of Mantis Shrimp Strikes: Interdisciplinary Impacts of an Extreme Cascade of Energy Release. Integr Comp Biol. 2019;59(6):1537-85. Available from: https://doi.org/10.1093/icb/icz127

10. Ramos FPA. Nota preliminar sobre alguns Stomatopoda da costa Brasileira. Bol Inst Pesca. 1951;1:140-50.

11. Ahyong ST, Harling C. The phylogeny of the Crustacea Stomatopoda. Aust J Zool. 2000;48(6):607-42. Available from: http://dx.doi. org/10.1071/ZO00042

12. DeVries MS, Murphy EAK, Patek SN. Strike mechanics of an ambush predator: the spearing mantis shrimp. J Exp Zool. 2012;215(24):4374-84. Available from: http://doi:10.1242/jeb.075317
13. Anderson PSL, Claverie T, Patek SN. Levers and linkages: mechanical trade-offs in a power-amplified system. Evolution. 2014;68(7):1919-33. Available from: http://dx.doi.org/10.1111/evo.12407.

14. Caldwell RL, Dingle H. Stomatopods. Sci Am. 1976;234(1):80-9.

15. Patek SN, Korff WL, Caldwell RL. Biomechanics: Deadly strike mechanism of a mantis shrimp. Nature. 2004;428(6985):819-20. Available from: $\mathrm{http} / / \mathrm{dx}$.doi.org/10.1038/428819a

16. Patek SN. Extreme impact and cavitation forces of a biological hammer: strike forces of the peacock mantis shrimp Odontodactylus scyllarus. J Exp Biol. 2005;208(19):3655-64. Available from: http://dx.doi. org/10.1242/jeb.01831

17. Cox SM, Schmidt D, Modarres-Sadeghi Y, Patek SN. A physical model of the extreme mantis shrimp strike: kinematics and cavitation of Ninjabot. Bioinspir Biomim. 2014;9(1):016014-016030. Available from: http://dx.doi.org/10.1088/1748-3182/9/1/016014

18. Humann P, Deloach N, Wilk L. Reef creature identification. Florida, Caribbean, Bahamas. 2nd ed. Florida: Jacksonville Publications, Inc.; 1993. $295 \mathrm{p}$.

19. Haddad Jr V. Atlas de animais aquáticos perigosos do Brasil: Guia médico de identificação e tratamento. 1st ed. São Paulo: Editora Roca; 2000. 145 p.

20. Haddad Jr V. Animais aquáticos potencialmente perigosos do Brasil: Guia médico e biológico. 1st ed. São Paulo: Editora Roca; 2008. 268 p.

21. Haddad Jr V. Animais aquáticos de importância médica no Brasil. Rev Soc Bras Med Trop. 2003;36(5):591-7.

22. Secretaria Municipal de Turismo [Internet]. Barra dos Pescadores. Ubatuba: Prefeitura Municipal de Ubatuba; 2019 [updated Dec 2018; cited 2019 Dec 16]. Available from: https://turismo.ubatuba.sp.gov.br/ pontosturisticos/barra/

23. Haddad Jr V. Medical emergencies caused by aquatic animals. Springer Nature. Switzerland: Springer International Publishing; 2016. 123 p. Available from: http://dx.doi.org/10.1007/978-3-319-20288-4 